\title{
The Safety of Water Supplied at Njala University, Njala Campus
}

\author{
Abubakarr S. Mansaray ${ }^{1 *}$, Josehpus F. Borsuah¹, Alhaji B. Gogra1, Binty P. Fofana1, \\ Bashiru M. Koroma²
}

${ }^{1}$ Chemistry Department, Njala University, Njala, Sierra Leone

${ }^{2}$ School of Community Health Sciences, Njala University, Njala, Sierra Leone

Email: *absmansaray@gmail.com

How to cite this paper: Mansaray, A.S., Borsuah, J.F., Gogra, A.B., Fofana, B.P. and Koroma, B.M. (2017) The Safety of Water Supplied at Njala University, Njala Campus. Natural Resources, 8, 81-93. https://doi.org/10.4236/nr.2017.82006

Received: August 27, 2016

Accepted: February 5, 2017

Published: February 8, 2017

Copyright @ 2017 by authors and Scientific Research Publishing Inc. This work is licensed under the Creative Commons Attribution International License (CC BY 4.0).

http://creativecommons.org/licenses/by/4.0/

c) (i) Open Access

\begin{abstract}
The safety of water is usually determined by comparing its quality to recommended standards. The objective of this work was to determine whether the water supplied on Njala Campus is safe for drinking. The quality parameters investigated include coliform bacteria, turbidity, conductivity, total dissolved solids and nitrates. Samples were stored in a cooler with ice and transported to the laboratory within 30 minutes of collection. A checklist of questions to know the perception of residents was administered. According to the physical and biological results, the water is not safe for consumption. The turbidity and microbial counts were too high in most samples both in the wet and dry seasons. Additionally, over $80 \%$ of the respondents did not trust the water supply system. Most of them treat the supplied water by either boiling or disinfection before use. Most respondents complained of water-borne diseases but were not clear whether it is related to the water supplied. The chemical parameters, however, were acceptable: nitrate levels were low. In conclusion, the water is not safe for consumption as far as the physical and biological parameters are concerned. The campus water supply system needs improvement in terms of conveying raw and finished water, filter optimization, and satisfying the chlorine demand.
\end{abstract}

\section{Keywords}

Safety, Drinking Water, Raw Water, Finish-Water, Chlorine Demand, Filter

\section{Introduction}

The safety of water is determined through comprehensive risk assessment and risk management approaches that include the setting up of regulatory standards. Different countries and agencies have developed chemical, biological and physi- 
cal standards to meet before water is considered to be safe for human use.

According to the Washington State Department of health (2011), fecal coliform bacteria are a subgroup of total coliform bacteria. They exist in the intestines and feces of people and animals. Their presence in a drinking water sample often indicates recent fecal contamination. That means there is a greater risk that pathogens are present. High non-fecal coliform count is indicative of either inhibiting fecal coliform growth or poor filtration of samples [1]. The Nigerian Standard for Drinking Water Quality covers all drinking water except mineral water and packaged water. The maximum allowable limit for turbidity is 5 NTU, nitrates, $50 \mathrm{mg} / \mathrm{L}$; total dissolved solids (TDS), $500 \mathrm{mg} / \mathrm{L}$; and thermo tolerant coliform or E. coli, zero [2]. The Ghana standards for drinking water [3] indicate the required physical, chemical, and microbial properties for drinking water. The standards are adapted from the WHO Guidelines for Drinking Water Quality [4], but also incorporate national standards that are specific to the country's environment. The Ghana standards set the maximum turbidity of drinking water at 5 NTU. The Standards specify that E. coli or thermo-tolerant coliform bacteria and total coliform bacteria should not be detected in a $100 \mathrm{~mL}$ sample of drinking water $(0 \mathrm{CFU} / 100 \mathrm{~mL})$.

Unlike these countries, Sierra Leone is yet to develop national water quality standards. Until this happens, the current water treatment system at Njala campus is subjected to no known national regulation that can ensure production and distribution of safe drinking water to residents. Nonetheless, the university authorities have taken some measures to treat the water before supplied to residents. Water is pumped from source at the Taia River. The raw water pump is immersed in the river at the intake point, which lifts water over a distance of about 400 meters to the treatment center, the Water Works. At the Water Works, the water passes through Slow Sand Filters. The filters are constructed using graded layers of sand, with the coarsest along with some gravel at the bottom, and the finest at the top. There is no backwash mechanism in place; the filters are maintained by physical removal of the top layer of sand when flow is constrained by biological growth or there is increased turbidity. The filtered water passes through pipes to a disinfection tank where it is being chlorinated manually by the staff. The treated water is stored in a finish water tank to await distribution by gravity flow to staff quarters, administrative buildings and student hostels.

The only quality parameter tested for at the Njala Campus Water Works is turbidity. The staff use a transparent glass cylinder with a mark at the base for tracing water clarity. The point at which the mark disappears reads the turbidity value. This instrument is based on estimates and it is difficult to tell whether turbidity exceeds the WHO standard of 5 NTU. This absence of quality control test at the Water Works made the need for quality profiling of water supplied to campus important. To show whether water is safe for drinking, it should be tested for the physical, chemical and biological contaminants [4].

Additionally, there is no monitoring of the raw water source to determine the 
chlorine demand, filter optimization needs, and chemical treatment needs. The lack of backwash makes it difficult for an efficient and sustainable filtration process; yet most microorganisms hide inside suspended particles and are inaccessible to the chlorine added [4]. Another water quality concern is that the pipes may introduce harmful chemicals or easily break and cause reintroduction of harmful microorganisms in the supply chain [5]. The objective, therefore, is to determine through laboratory tests and perception survey whether the water supplied on Njala Campus is safe for drinking. Quality parameters for analysis include the following: Bacteriological: Fecal and non-fecal coliform bacteria in water samples; Physical: Turbidity in water samples; Physico-chemical: Conductivity and Total Dissolved Solids (TDS) in water samples; Chemical: Chemical Oxygen Demand and Nitrate in water samples.

\section{Materials and Methods}

The research was done at Njala Campus found in the Kori Chiefdom of Moyamba District in southern Sierra Leone (Figure 1). The case study for the research starts from the Taia River, the water works, staff quarters, student dormitories, and administrative buildings through to the secretariat. The study area is located within the surrounding campus of Njala University at Latitude $8^{\circ} 07^{\prime}$ North and Longitude $12^{\circ} 05^{\prime}$ West on the tropical map of Sierra Leone, scale $1: 50,000$.

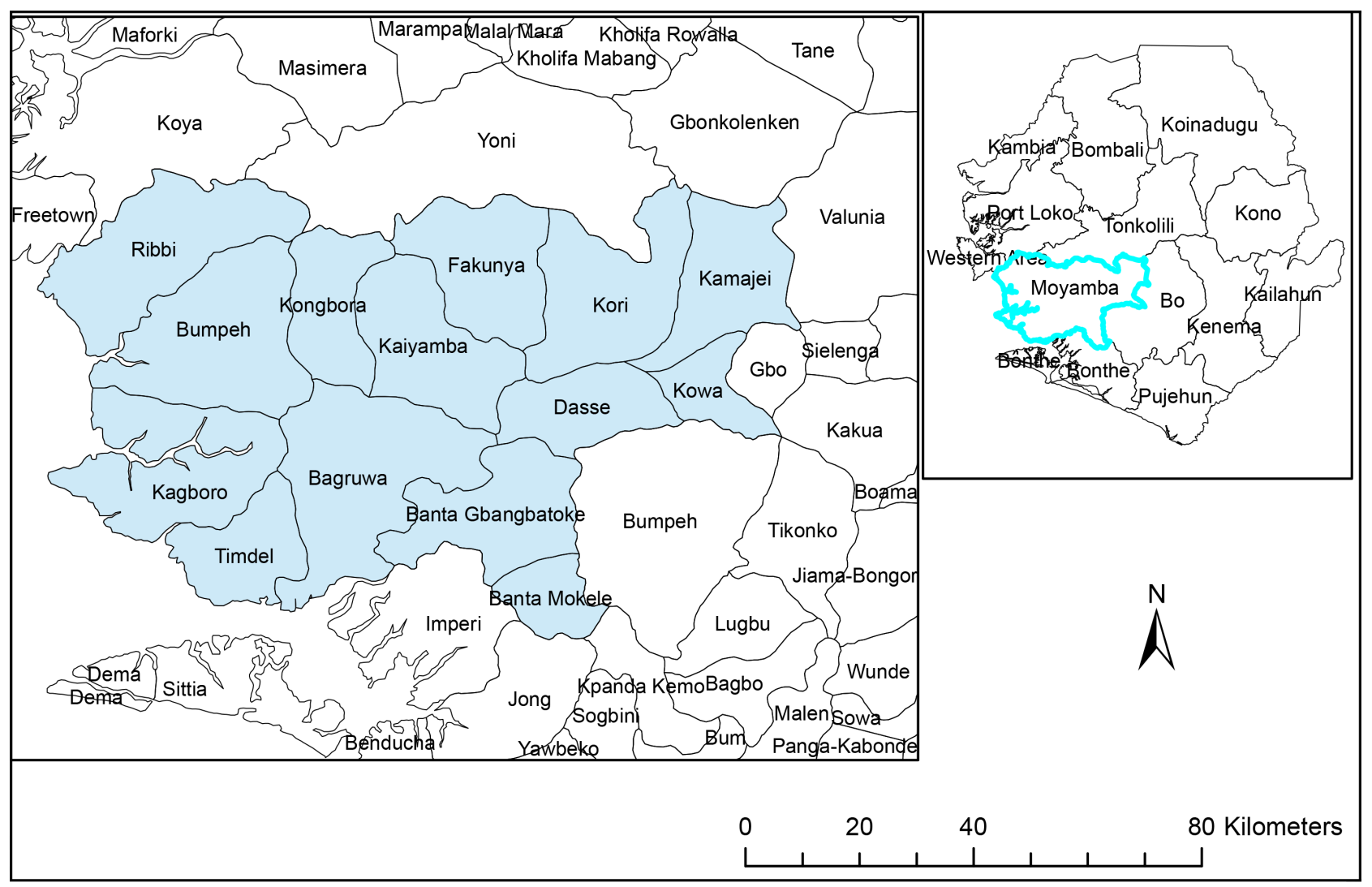

Figure 1. Map of Sierra Leone showing Moyamba District and Kori Chiefdom. 


\subsection{Sampling}

The research targets the entire water supply network within Njala campus. Water samples were collected and analyzed for both the rainy and dry seasons. This was done in order to understand the influence of surface runoff on the quality of water supplied. Plastic bottles were sterilized by boiling and used to collect samples from each point. The sampling points and their GPS coordinates are shown in Table 1.

\subsubsection{Water Sampling}

Plastic bottles were washed clean, boiled and labeled accordingly. Each sample bottle was rinsed thrice with the sample to be collected before the actual sample was collected and closed tightly with the cover. All samples were transported to the laboratory within 30 minutes of collection. Samples were stored in a cooler with ice in order to approximate the prevailing conditions under which they were collected.

1) Procedures for Sample Analysis

In the determination of conductivity in microsiemens per centimeter $(\mu \mathrm{s} / \mathrm{cm})$ and total dissolved solids (TDS) in milligram per liter $(\mathrm{mg} / \mathrm{L})$, the probe was placed into the water sample and allowed to read, a pause of reading indicated the end of readings and values were noted. The $\mathrm{HACH}$ turbidity meter was used in determining the turbidity of the sample. The samples were put into the test tube and then inserted into the turbidity meter which read in Nephelometric Turbidity Units. The Oxfam Delagua Water Testing Kit was used for bacteriological examination. The kit has a petridish, absorbent pads, membrane filters, vacuum pump and grease. In order to prevent any form of contamination, the equipment and all other accessories were sterilized. Each sample was gently shaken for a minute to make sure there was an even distribution of micro-organisms

Table 1. GPS coordinates of sample locations.

\begin{tabular}{ccc}
\hline \multirow{2}{*}{ Description } & \multicolumn{2}{c}{ Coordinate $\left(^{\circ}\right)$} \\
\cline { 2 - 3 } & North & West \\
\hline Taia River (Intake) & 8.11284 & -12.08188 \\
Water Works & 8.11101 & -12.08056 \\
Senior Staff Quarters (SSQ) & 8.11200 & -12.07895 \\
Common Room & 8.11198 & -12.07512 \\
L Quarters (LQ) & 8.11214 & -12.06897 \\
Winters & 8.11444 & -12.07131 \\
Secretariat & 8.12476 & -12.06287 \\
Florence Carew (FC) & 8.11744 & -12.06768 \\
Y4 Quarters & 8.11029 & -12.07324 \\
Matturi & 8.11864 & -12.07022 \\
Crown Agent & 8.11825 & -12.07242 \\
\hline
\end{tabular}


present. $50 \mathrm{~mL}$ of the water sample was measured using a standard sterilized measuring cylinder and gently poured into the filtration assembly. With the application of the vacuum pump, the water sample was allowed to flow through the membrane filter of pore size 0.45 microns. The membrane filter was incubated for 18 - 22 hours at $44^{\circ} \mathrm{C}$ in order to form suitable colonies of characteristic shape and color. Yellow Colonies were formed for the fecal coliform and other colors for the non-fecal coliform bacteria. The coliform bacteria were computed as counts per $100 \mathrm{ml}$ of water sample as follows: [Number of colony forming unit/Volume of water sample filtered $(50 \mathrm{~mL})] \times 100$.

The reagent for nitrate was already prepared in the sample vial. A $1.0 \mathrm{~mL}$ volume of the sample was placed into the reagent and the solution inverted two to three times. The solution was allowed to stand for 10 minutes and then placed into the sample compartment, energized and readings taken.

\subsubsection{Perception Survey}

A list of questions was administered to residents as well as workers on Njala Campus. The questionnaires were distributed through lecturers and department heads. $10 \%$ of the respondents were further engaged in a focus group discussion (FGD) after their individual responses. The FGD participants were selected based on departmental representation. A total of 136 respondents were interviewed; Njala campus has a working population of about 1200 people, most of whom are resident on campus.

\section{Results and Discussions}

\subsection{Water Quality Profiling of the Study Area}

\subsubsection{Conductivity}

The WHO recommended guidelines for conductivity is $100 \mu \mathrm{s} / \mathrm{cm}$. All the samples collected in both seasons satisfied this recommended value (Figure 2). Based on the WHO (2011) report, no direct health effect has been associated with electrical conductivity, albeit the assertion by Nyallay (2011) that toxic chemical substances which find their way into water bodies can cause water borne diseases [6]. Additionally, the fluctuation in conductivity at different locations is a cause for concern, giving that the water came from the same source. There may be corrosion in the pipes or redox conditions changing along the supply chain.

Conductivity values were higher in the rainy season than in the dry season. Apparently, surface runoff is introducing more ions into the water at this time of the year. Alternatively, or additionally, incoming groundwater is probably bringing in dissolved solids.

\subsubsection{Turbidity}

Three replicate samples were collected from each sample location and the mean value recorded; the results are shown in Figure 3. As expected, wet season samples recorded higher turbidity values than those in the dry season. Flash floods erode a lot of debris and transport into the river. These wet season turbidity values are expected to increase during the peak rainy season, following the trends of 


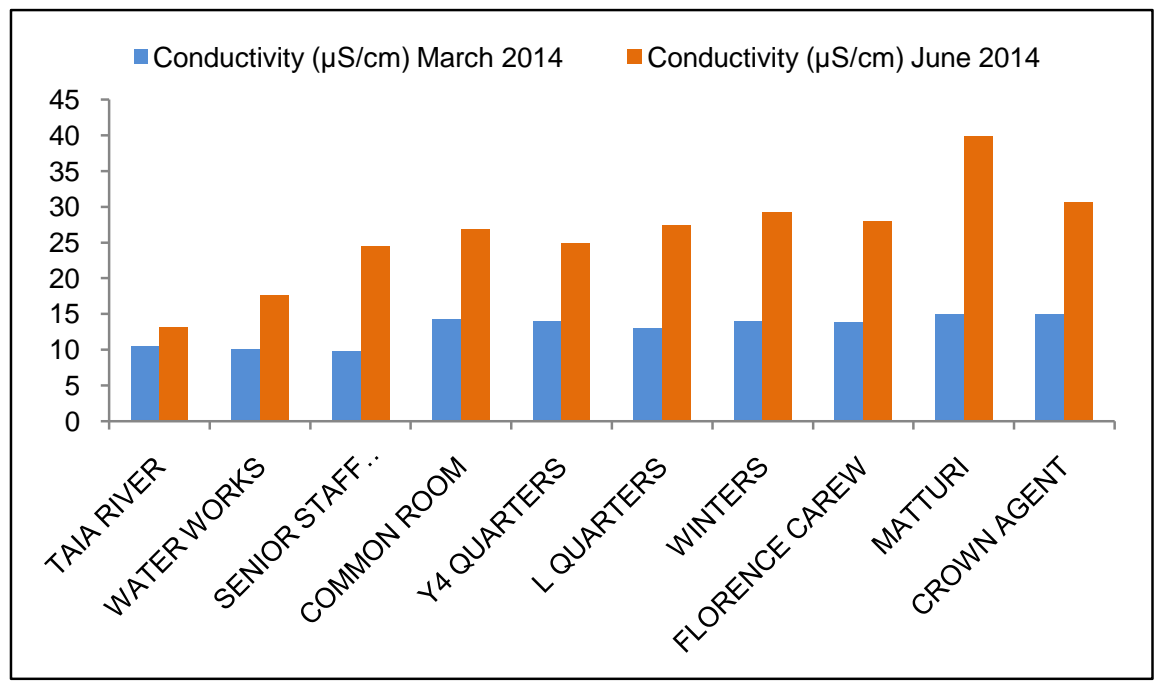

Figure 2. Conductivity in water samples from the study area.

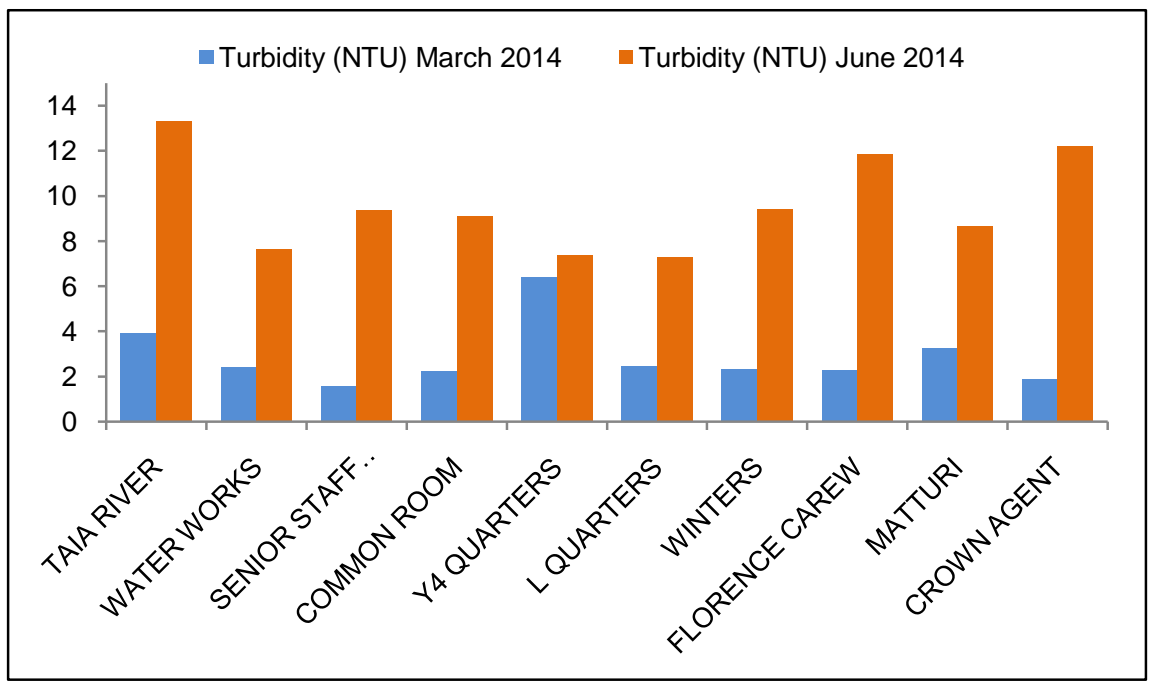

Figure 3. Turbidity readings (NTU) in samples from the study area.

heavier rain events and subsequent erosion of materials [7]. With the exception of Y4 Quarters, all the water samples met the WHO recommended guideline of less than $5 \mathrm{NTU}$ in the dry season. This is expected as surface runoff gets to zero during this time of the year [7]. The river shrinks in size and its turbulence decreases greatly. The river is very calm along its banks and hence bank erosion is minimal.

During the rains, the mean values for all the samples did not satisfy the WHO recommended standard of $\leq 5 \mathrm{NTU}$. The rise and fall in values is also a cause for concern. It is not clear whether the same water supplied from Water Works is the one having fluctuating values. Nevertheless the above standard turbidity values indicate the treated water is unsafe for consumption. Suspended particles might not contain harmful chemicals but may harbor harmful microorganisms that become inaccessible for disinfection by the added chlorine [8]. Aesthetically, the muddy water renders the water unsuitable for drinking or any other domes- 
tic use. High turbidity at locations further from the treatment site may be due to the presence of suspended solids and other colloid particles which may have been collected along the pipeline. Clarification of this turbidity increase along the supply chain was, however, beyond the scope of this study. Nonetheless, change in turbidity was measured in the raw and finished water tanks, respectively. These measurements revealed that treatment efficiency of the filter media was $39 \%$ in the dry season and $42 \%$ in the rainy season.

\subsubsection{Total Dissolve Solid}

The recommendation for a good drinking water gives TDS values ranging between 300 and $600 \mathrm{mg} / \mathrm{L}$ in drinking water [9]. The low values recorded (Figure 4) are consistent with the prevailing conditions in the river. Total Dissolved Solids in natural waters may change resulting from industrial discharge or saline water intrusion [10].

All the samples collected in both seasons met the WHO standard of $300-600$ $\mathrm{mg} / \mathrm{l}$ which indicate that the water does not contain much dissolved solids. Again, fluctuations in values are a cause for concern and may be caused by leaks in the pipes.

\subsubsection{Microbial Parameters for Wet and Dry Seasons}

\section{1) Fecal Coliform Bacteria}

Table 2 shows fecal and no-fecal coliform counts in samples from both raw water (Taia River) and treated water at the taps. All the samples collected during the wet season did not meet the WHO recommended standard of zero counts/ $100 \mathrm{~mL}$ of sample. The samples were highly contaminated with harmful microorganisms, most of them too numerous to count, even after treatment of the water. The high microbial count in the raw water sample could be related to open defecation and such human waste ending into the river through surface runoff; other sources include direct defecation into the river, as well as other domestic sources of biota [11]. The presence of microorganisms in the treated

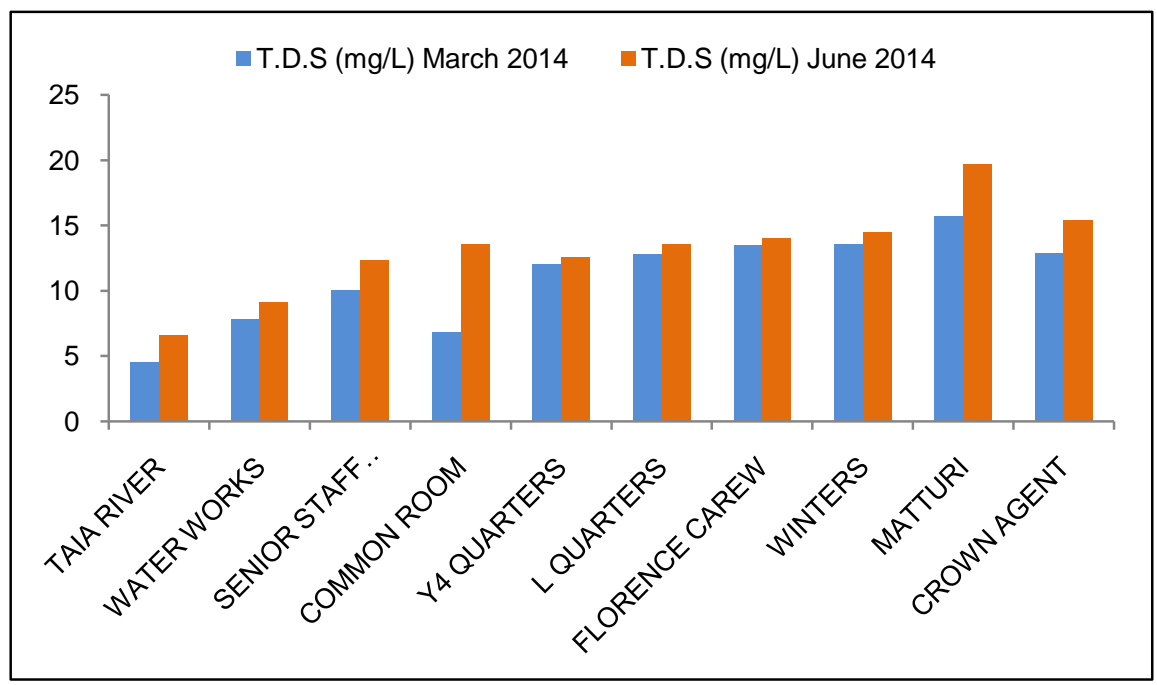

Figure 4. TDS (mg/L) in samples from the study area. 
Table 2. Microbiological characteristics of water samples collected both in the wet and dry seasons.

\begin{tabular}{ccccccc}
\hline \multirow{2}{*}{ Sample location } & \multicolumn{2}{c}{ Fecal Coliform Bacteria } & & \multicolumn{2}{c}{ Non-Fecal Coliform Bacteria } \\
\cline { 2 - 3 } \cline { 5 - 6 } & March 2014 & June 2014 & & March 2014 & June 2014 \\
\hline Taia River (Raw water) & 34 & TNTC & & 382 & TNTC \\
Water Works (Finished tank) & 8 & 22 & & 62 & 29 \\
Senior Staff Quarters & 18 & TNTC & & 14 & TNTC \\
Common Room & 4 & TNTC & & 8 & TNTC \\
Y4 Quarters & 2 & 36 & & 20 & 50 \\
LQuarters & 2 & 68 & & 34 & 28 \\
Winters & 18 & TNTC & & 20 & TNTC \\
Florence Carew & 22 & TNTC & & 0 & 0 \\
Matturi & 4 & TNTC & 82 & 35 \\
Crown Agent & 0 & 43 & 6 & TNTC \\
\hline
\end{tabular}

TNTC $=$ Too Numerous to Count.

water is reflective of poor treatment and poor infrastructure. Clearly, residual disinfection is not reflective of the chlorine demand in the water. The manual addition of chlorine does not take into account when is disinfection too much or too little.

Similarly, all the samples collected during the dry season did not meet the WHO standards except Florence Carew which had a count of zero counts/ $100 \mathrm{~mL}$ of sample. The count in the raw sample was very high and it could be related to human activities along the river: defecation, bathing, dumping of sewage into the river. The lower count of fecal coliform in the dry season, compared to the rainy season, is expected because there is low surface runoff and less intake of organic carbon into the water [11].

Even though disinfection efficiency seemed to be high $(76 \%$ in the dry season and $89 \%$ in the wet season) the finish water still needed further disinfection as there was fecal coliform counts still greater than the WHO recommended limits. The $89 \%$ efficiency in the wet season might have been due to too numerous of bacteria in the water; since they are plenty, contact with chlorine is fast. For computation purpose this research approximates TNTC to a minimum of 200 fecal coliform counts $/ 100 \mathrm{~mL}$ of sample.

It could be inferred from these results that residual disinfection during both sampling periods was not effective; the chlorine demand was too high and so all the added chlorine was consumed. This assumption is more obvious giving the increase in microbial counts along the supply chain. Worthy of note however, is the uncertainty as to whether the same water sampled at the finished tank was the one supplied from which samples were collected at the taps.

During this study, it was observed that the staff did not set contact time at the finish water tank. The contact time allows for complete dispersal of chlorine which would enhance contact with and subsequent destruction of microorgan- 
isms [12]. The possible existence of dead zones in the finish water tank might also play a role in the lack of complete disinfection in the finished water tank. The lack of baffle systems in the finish water tank or the complete absence of contact tank makes this assumption more obvious [13]. Consequently, the current treatment system is incapable of bringing the campus water to safety standards based on fecal contamination. Further optimization of the system is required to enhance international best practice for drinking water treatment works.

2) Non-Fecal Coliform Bacteria

The WHO recommended standard for non-fecal coli form is $<10 \mathrm{CFU}$ (Colony Forming Units) [4]. All the samples collected for the wet season did not meet the WHO recommended standard except Florence Carew which have a count of zero counts $/ 100 \mathrm{~mL}$ of sample. The high microbial count of the intake point may be as a result of agricultural activities, poultry and other domestic activities of the people living along the river [11]. The high microbial count of other samples may be a cause of leaks in the pipes, or a higher chlorine demand which was not met in the treatment process [12]. The non-fecal coli form counts in the dry season is recorded lower than the counts in the wet season. The rains erode materials and particles from anthropogenic and natural activities into the river, leading to high counts at the source and high counts at locations away from the treatment system.

\subsection{Nitrate in Water Samples}

All the samples met the WHO recommended standard of $<10 \mathrm{mg} / \mathrm{L}$; the highest was $0.3 \mathrm{mg} / \mathrm{L}$. This indicates that there is no susceptibility to toxicity from nitrates present in the water supplied to Njala campus. The nitrate results confirm the less concern for chemical pollution. Apparently the raw water is not chemically polluted. As a rural area with no major industrial activity, this is expected to be the case.

\subsection{Perception of Safety of Water Supplied on Njala Campus}

\subsubsection{Uses of Water Supplied on Campus}

Figure 5 shows results of the perception survey on campus. Out of the 136 respondents interviewed on campus, $86.7 \%$ use the water regularly at household level. The remaining respondents do not reside on campus, are on campus on occasional basis, or have alternative use sources. Because the respondents are not sure of the safety of the water only $19.8 \%$ drink the water and the remaining $80.1 \%$ have alternative means of drinking water such as groundwater and package (bottled and sachet) water. $88.9 \%$ of the respondents who use the water for bathing either boil or add disinfectants, while $11 \%$ use water from the campus hand dug well with hand pump for bathing. The respondents who use the tap water for laundry (88.9\%) believe that bacteria will be killed by the sun when the clothes are hung on lines in the Sun. $11 \%$ launder with water from the campus hand pump. When cooking with the water, the heat would kill the bacteria as believed by $88.9 \%$ of respondents who use the water for that purpose. 


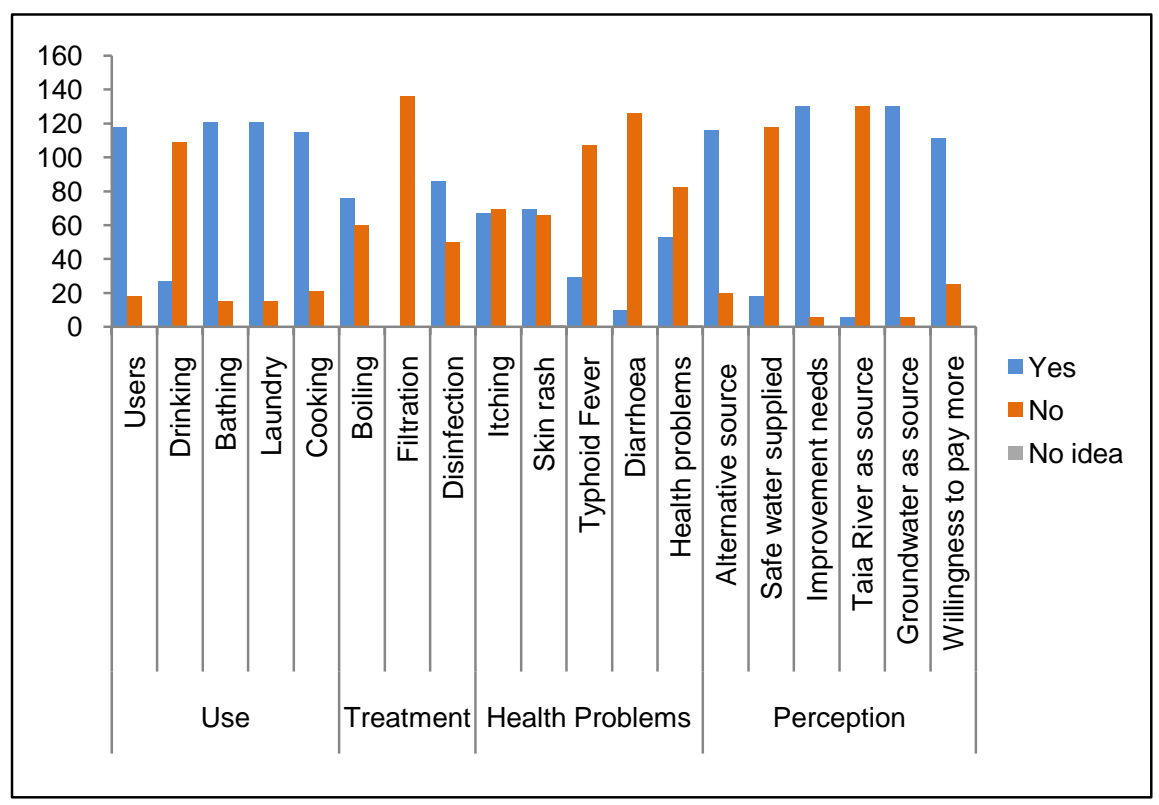

Figure 5. Perception of Safety of water supplied on Njala Campus.

\subsubsection{Further Treatment}

More than half of the respondents (55.8\%) who use the water boil it, the others (44.1\%) are either confident of the water's safety or add disinfectants to the water before use. Boiling as the predominant treatment option is reflective of the cost savings from this method compared to relatively costly disinfectants such as chlorine tablets.

\subsubsection{Health Related Problems}

Typhoid fever affects most of the respondents (80.1\%) likewise diarrhea (92.6\%) but, it is not clear whether these are as a result of the water; majority has alternative means of drinking water. Body itching and skin rash are reported by $49.2 \%$ and $50.7 \%$ respectively but are not sure if those health problems result from the water use because most of them either boil or disinfect the water before use. Most of the respondents (60.2\%) agree that their health problems are not related to the water supplied on campus.

\subsubsection{General Perception of Safety}

A large number of the respondents (85.2\%) do not rely on the water supplied on campus for drinking; they have alternative sources of drinking water. Also $86.7 \%$ believe the water supplied on campus is not safe, which is the same percentage as the people who use the water regularly on campus. This implies that most users do not have alternative access to water. Reliability in the treatment system could therefore be a development objective as far as water supply on campus is concerned.

Another source of water to be supplied on campus is requested by $95.5 \%$ because they are not sure of the safety of the Taia River and the treatment system. Alternatively, these respondents believe water from the river could be safe for consumption if proper treatment is in place. For now, they prefer groundwater 
instead of water from the Taia River. Majority of the respondents (81.6\%) are willing to pay more for water supply because they think paying more will provide the required resources to improve the water supply system.

The findings in the perception survey clearly reflect the attitude of consumers in developing countries. Most times consumers do not trust service providers, especially those in the public sector, probably because of corruption, incompetence, and dishonesty. The same attitude was reflected in the study conducted by de Queiroz et al. (2006) in assessing public perception and participation in bottled water sourced from taps in Brazil [14].

\section{Conclusions}

The objective of the work was to determine through laboratory tests and perception survey whether the water supplied to Njala University, Njala Campus is safe for drinking. Chemical, biological and physical tests were conducted on the samples collected from both the raw water and the treated water. Respondents were also interviewed to give their perception about the safety of water supplied on campus.

Chlorine demand of the water samples was found to be high. The bacteriological analyses showed that all the samples are highly contaminated with coliform bacteria; all the bacterial counts recorded did not meet the WHO recommended standards. The ineffectiveness of the existing campus water treatment system further clarifies this problem. The efficiency of the filtration system is not enough to reduce turbidity to acceptable levels; the disinfection system is also inadequate and there is no clue to ascertain whether the added chlorine is plenty enough to give residual disinfection. Consequently, unacceptable microbial counts were found in all stages of the supply chain. It is not clear whether additional microorganisms were introduced at leaks and broken points or microbial activity is increasing with distance.

The chemical status showed no potential threat to consumers. Nitrate levels in all the samples were below the maximum contaminant limit recommended by standards organizations and agencies.

Majority of the respondents did not trust the safety of water supplied on campus. Most of them treat the water by either boiling of adding disinfectants before use. Very few of them drink the water, after boiling. Some respondents reported health problems related to water quality but were not sure if such problems are sourced from water supply on campus.

Conclusively, the water supplied to the residents of Njala University Njala campus is not safe for drinking. It would be only safe for domestic purposes if further treatment (filtration and/or boiling) is ensured. The lack of safety is not as a result of the source; the Taia River has been proven to be a good source for drinking water (low TDS). The problem lies with the treatment center. The current treatment scheme is inadequate in bringing the water to acceptable standards for drinking. The following recommendations are put forward in helping to improve the treatment system. 


\subsection{Monitoring}

Routine monitoring of the source would inform filtration and disinfection needs. These are the two most important requirements for the Njala Campus potable water supply system. Clarifying these two treatment needs will inform customization of the treatment system and hence enhance supply of potable water to campus and neighboring communities.

The Njala Campus Water Works team needs both human and institutional capacity building in monitoring the quality of raw and treated water. As at now there are no Quality Control (QC) tests of batches of water sent to campus. This does not enhance quality assurance, hence, the lack of trust in consumers. The team needs a QC laboratory equipped with the right instruments and reagents with assurance of recurrent costs. Thankfully the residents are willing to pay for additional charges. Alternatively, the Chemistry Department and the Institute of Environmental Management and Quality Control could take the lead in the monitoring network and provide technical advice in improving the water supply system on Campus.

\subsection{Improvement in Treatment and Supply}

It is recommended that the campus supply system be optimized to a solar pumping system and an automatic control panel to shut down and alarm when the chlorine demand is too high or too low, and to initiate backwash when the filter media accumulate too much dirt. Solar panels will be deployed to run solar pumps on a 24-hour basis. The solar system will have an electrode attached to carry out electrolysis of sodium chloride in water, to prepare the disinfectant solution. The whole system will be customized to dose the right chlorine solutions based on the chlorine demand established by the control panel.

Improvement in pipes and leaks is also recommended. The residents are willing to pay for an improved service. Currently they spend money on the purchase of drinking water from alternative sources, in addition to contribution to plastic waste accumulation on campus.

\section{References}

[1] Washington State DOH (2016) Coliform Bacteria and Drinking Water. http://www.doh.wa.gov/portals/1/Documents/Pubs/331-181.pdf

[2] SON (2007) Nigerian Standard for Drinking Water Quality. Sttandard Organization Nigeria (SON).

[3] GSB (2009) Water Quality Specification for Drinking Water. 3rd Edition, Ghana Standards Board, Accra.

[4] WHO (2011) Guidelines for Drinking-Water Quality. 4th Edition, World Health Organization.

[5] Fawell, J.K. (2002) Asbestos Cement Drinking Water Pipes and Possible Health Risks. Devizes, Wiltshire.

[6] Nyallay, M.R. (2011) Taia River Regime Water Quality Assessment, Taiama Highway Bridge to Waifor Crossing. Njala University, Njala.

[7] Robert, E., Grippa, M., Kergoat, L., Pinet, S., Gal, L., Cochonneau, G. and Martinez, 
J.-M. (2016) Monitoring Water Turbidity and Surface Suspended Sediment Concentration of the Bagre Reservoir (Burkina Faso) Using MODIS and Field Reflectance Data. International Journal of Applied Earth Observation and Geoinformation, 52, 243-251. https://doi.org/10.1016/j.jag.2016.06.016

[8] Stauber, C.E., Elliott, M.A., Koksal, F., Ortiz, G.M., DiGiano, F.A. and Sobsey, M.D. (2006) Characterisation of the Biosand Filter for E. coli Reductions from Household Drinking Water under Controlled Laboratory and Field Use Conditions. Water Science and Technology, 54, 1-7. https://doi.org/10.2166/wst.2006.440

[9] WHO (2003) Total Dissolved Solids in Drinking-Water. World Health Organization, Geneva.

[10] McHenry, M.P. (2013) Hybrid Microalgal Biofuel, Desalination, and Solution Mining Systems: Increased Industrial Waste Energy, Carbon, and Water Use Efficiencies. Mitigation and Adaptation Strategies for Global Change, 18, 159-167. https://doi.org/10.1007/s11027-012-9361-y

[11] Ghimire, N.P., Caravello, G.U. and Jha, P.K. (2013) Bacterial Contamination in the Surface Water Bodies in Sagarmatha National Park and Buffer Zone, Nepal. Scientific World, 11, 94-96. https://doi.org/10.3126/sw.v11i11.8560

[12] Angeloudis, A., Stoesser, T. and Falconer, R.A. (2014) Predicting the Disinfection Efficiency Range in Chlorine Contact Tanks through a CFD-Based Approach. Water Research, 60, 118-129. https://doi.org/10.1016/j.watres.2014.04.037

[13] Angeloudis, A., Stoesser, T., Falconer, R.A. and Kim, D. (2015) Flow, Transport and Disinfection Performance in Small- and Full-Scale Contact Tanks. Hydro-Environment Research, 9, 15-27. https://doi.org/10.1016/j.jher.2014.07.001

[14] de Queiroz, J.T.M., Doria, M.D.F., Rosenberg, M.W., Heller, L. and Zhouri, A. (2013) Perceptions of Bottled Water Consumers in Three Brazilian Municipalities. Water and Health, 11, 520-531. https://doi.org/10.2166/wh.2013.222

\section{Submit or recommend next manuscript to SCIRP and we will provide best service for you:}

Accepting pre-submission inquiries through Email, Facebook, LinkedIn, Twitter, etc. A wide selection of journals (inclusive of 9 subjects, more than 200 journals)

Providing 24-hour high-quality service

User-friendly online submission system

Fair and swift peer-review system

Efficient typesetting and proofreading procedure

Display of the result of downloads and visits, as well as the number of cited articles

Maximum dissemination of your research work

Submit your manuscript at: http://papersubmission.scirp.org/

Or contact nr@scirp.org 